\title{
Svo bregðast krosstré sem önnur tré
}

Í daglegu lífi leggjum við oft mikið traust á flókna tækni. Við tökum pví sem gefnu að pessi tækni sé örugg og að hún bregðist ekki pví hlutverki sínu. Ekki síður göngum við út frá pví að vandvirkni sé höfð að leiðarljósi við hönnun tækja sem styðjast við flókna tækni og að ítrustu kröfur séu gerðar um prófun. Pegar alvarleg frávik koma upp er varða flókinn tækjabúnað vekur pað pví gjarnan bæði undrun og athygli. Fréttaflutningur síðustu mánaða um kerfislægan galla í hönnun og ófullnægjandi prófanir á Boeing 737 MAX flugvélum ber pessu glögglega vitni.

Læknisfræði nútímans er sömuleiðis oft á tíðum verulega háð flóknum tækjum og tólum. Við græðum nú orðið fjölbreytileg tæki í sjúklinga til að bæta líðan peirra og jafnvel lengja líf. Gangráđar og bjargráđar eru gott dæmi um slíkt. Ef pessi tæki bila eða sinna ekki hlutverki sínu getur pað stundum valdið alvarlegum skaða. Ástæðurnar fyrir pví að ígrædd lækningatæki valda ekki pví hlutverki sem til var ætlast eru auðvitað margpættar, allt frá galla í hönnum, bilun eða einfaldlega rangri notkun peirra. Öll ígrædd lækningatæki hérlendis eiga að hafa öðlast svokallaða CE-merkingu (Conformité Européenne) sem er staðfesting á pví að framleiðsla peirra standist ákveðnar kröfur Evrópusambandsins. Prátt fyrir að áreiðanleiki og öryggi gangráða og bjargráða sé með ágætum hafa komið upp gallar eða ófyrirséðar bilanir pó sjaldgæft sé. ${ }^{1}$

Bjargráðar hafa gjörbylt horfum peirra sem lifa af hjartastopp eða eru taldir vera í sérstakri áhættu á slíku. ${ }^{2}$ Bjargráđur er græddur undir húð á brjóstkassa og liggur leiðsla frá honum gegnum efra bláæðakerfi líkamans til hjartans. Bjargráður getur brugðist við sleglahraðtakti meðal annars með pví að gefa rafstuð. Notkun bjargráða hefur farið vaxandi og eru tæplega 400 Íslendingar með svona tæki.

Fyrir nokkrum árum kom í ljós galli í Riata-bjargráðsleiðslum sem voru talsvert notaðar hérlendis á árunum 2002 til 2009. Pessar leiðslur voru með nýstárlegri hönnun, sem gat leitt til pess að einangrun peirra rofnaði og truflanir í starfsemi gat leitt til óréttmætra rafstuða eða jafnvel pess að rafstuð væri ekki gefið pegar við átti.

Nýlega birtu Gústav Arnar Davíðsson og samstarfsmenn niðurstöður rannsóknar í tímaritinu JAMA Internal Medicine á íslenskum sjúklingum sem höfðu fengið Riata-leiðslu. ${ }^{3}$ Í ljós kom að peir sem voru með Riata-leiðslu voru í mun meiri áhættu á leiðslubilun en samanburðarhópur sem fékk leiðslu frá öðrum framleiðanda. Rúmlega priðjungur Riata-hópsins fékk einhvers konar frávik, mörg peirra alvarleg, á móti $8 \%$ samanburðarhópsins. Pessi galli leiddi pví til umtalsverðs vanda hérlendis.

Vísbendingar höfðu verið um að ekki væri allt með felldu með leiðsluna í nokkur ár áður en framleiðslu- fyrirtækið St Jude Medical greindi opinberlega frá pví og afturkallaði hana seint árið 2011. Hlaut fyrirtækið talsverða gagnrýni fyrir að bregðast seint við, sem og eftirlitsstofnanir, ekki síst Bandaríska lyfjaeftirlitið. Spunnust talsverðar umræður um hefðbundinn feril pess pegar galli kemur fram í lækningatæki. Venjan hefur verið sú að notendur tilkynna framleiðslufyrirtækinu fyrst um frávik, eins og í tilviki Riata-leiðslunnar, og svo eru lögformlegum eftirlitsaðila sendar upplýsingar. Notendur tilkynna pó ekki alltaf atvik pegar pað er ekki talið alvarlegt eða stafar af eðlilegu sliti. Bæði framleiðslufyrirtækið og Bandaríska lyfjaeftirlitið bera pví við að par sem um stök dreifð tilfelli hafi verið að ræða hafi tekið langan tíma að sjá mynstur.

Раð eru ákveðin hagsmunatengsl fólgin í pví að fyrirtæki rannsaki sjálf mögulegt vandamál við notkun eigin vöru. Á móti má segja að pað séu kannski fáir tæknilega jafn vel til pess fallnir, par sem framleiðsluaðilinn gjörpekkir jú sína sérhæfðu vöru. Í tilviki Riata-leiðslunnar hefði fjöldi tilkynntra frávika sennilega átt að leiða til aðgerða fyrr. Рað hefði mögulega gerst ef hlutlaus eftirlitsaðili hefði haft aðgang að öllum gögnunum. Eftir að tilkynning um afturköllun barst frá St Jude Medical var farið að fylgjast með pessum tækjum, par á meðal hérlendis, á mun nákvæmari hátt. Undanfarin ár höfum við tekið upp svokallaða fjarvöktun á öllum nýjum bjargráðum sem eykur öryggi pessara sjúklinga verulega.

Vandamálið með Riata-leiðsluna er ekki pað fyrsta er varðar gangráða eða bjargráða. Eftir stendur pó áleitin spurning um hvað við höfum lært og hvernig við getur bætt árvekni okkar og viðbrögð. Hérlendis er Lyfjastofnun eftirlitsaðili með ígræddum lækningatækjum. Stofnunin er háð pví að framleiðendur og notendur sendi peim tilkynningar um atvik sem kunna að koma upp. Раð parf að efla samskiptin milli Lyfjastofnunar og peirra aðila sem sýsla með tækin, bæta eftirlitsfarvegi og bregðast á skýrari hátt við frávikum. Framleiðendur ígræddra lækningatækja, eftirlitsstofnanir, heilbrigðisstofnanir og heilbrigðisstarfsfólk eiga að geta gert betur en hingað til hvað petta varðar.

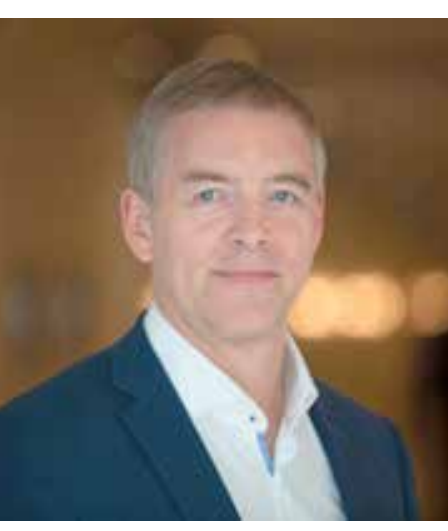

\section{Davío O. Arnar}

hjartalæknir

Landspítala Hringbraut

davidar@landspitali.is medical devices fail

David O. Arnar, MD PhD EMPH Chief of Cardiology Landspitali - The National University Hospital, 101 Reykjavik, Iceland.

\section{Heimildir}

1. Swerdlow CD, Kalahasty G, Ellenbogen KA. Implantable defibrillator lead failure and management. J Am Coll Cardiol 2016; 67: 1358-68.

2. Al-Khatib SA, Stevenson WG, Ackerman MJ. 2017 AHA/ACC/HRS Guideline for Management of Patients With Ventricular Arrhythmias and the Prevention of Sudden Cardiac Death: A Report of the American College of Cardiology/American Heart Association Task Force on Clinical Practice Guidelines and the Heart Rhythm Society. Circulation 2018; 138: e272-e391.

3. Davidsson GA, Jonsdottir GM, Oddsson H, Lund SH, Arnar DO. Long term outcome of cardioverter/defibrillator lead failure. JAMA Intern Med 2019/published online20122019. 